\title{
A rejoinder to Tily
}

\section{Marc Lavoie*}

As everyone knows, Keynes's General Theory has generated a lot of different interpretations. Geoff Tily presents a brief statement of his own understanding of it in his comment to my paper and he questions my perspective. There are also different strands of post-Keynesianism, as I have myself explained in a number of places. Tily is closest to what has been called Fundamentalist Post Keynesianism.

Tily is annoyed at my use of the word pirouette when authors such as himself try to make a distinction between a given, a constant or an exogenous money supply. ${ }^{1}$ Besides this, I believe his main point is that the General Theory was all about liquidity preference, that Keynes was more concerned with monetary policy than fiscal policy and that he favoured a cheap money policy. A quote that often comes to my mind is Keynes's $(1936, p$. 322) claim that "the remedy for the boom is not a higher rate of interest but a lower rate of interest!". Thus I would certainly agree with Tily in this regard. But Keynes (1936, p. 320) also said that "there is, indeed, force in the argument that a high rate of interest is much more effective against a boom than a low rate of interest against a slump", reinforcing the belief among many of us that monetary policy has limits that require the use of fiscal policy. Before the Great Recession and much before neoclassical Keynesians started relying on the interest rate zero-lower bound, post-Keynesians - among which Fazzari (1994-95), Galbraith (1994-95) and Arestis and Sawyer (2004) - have endorsed the relevance of fiscal policy at a time when mainstream economist were denying it.

Tily (p. 162) makes the surprising claim that "most post-Keynesians were little better prepared for the global financial crisis than the rest of the profession". I cannot share this opinion, and it is certainly not the view of Bezemer (2010) or Galbraith (2009), just to name a few. Tily seems to put the blame on the fact that post-Keynesians would have ignored the long-term consequences "of the restoration of dear money from 1980". As a partial response I could say that back in the 1980s, with a colleague of mine, I did write a piece on the detrimental effects of the high real interest rates that had started to be imposed by central banks in developed countries (Lavoie and Seccareccia, 1988).

Tily (page 162) is also baffled as to "why post-Keynesians spend so much energy trying to show Keynes as wrong". I did not feel that this was the intent of my paper, quite the contrary. However, as can be found in the statement of purposes of the Journal of Post Keynesian Economics, I consider that attachment to Keynes ought not to be "slavish nor theological despite the profound admiration to his work" (Editors, 1978, p.6). I certainly believe that I am free to express criticism of some of his views instead of trying to rationalize them if I assess that they are misguided. About this I also have the support of Hyman Minsky (1986), who held that "being post-Keynesian does not mean being slavishly dependent on the works of the Great Man".

\footnotetext{
* Senior Research Chair, Université Paris Sorbonne Cité, Université Paris 13 (Centre d'Économie de Paris Nord), and Emeritus professor at the University of Ottawa. Marc.Lavoie@uottawa.ca.

${ }^{1}$ I discussed the question of Keynes and endogenous money in a full-length article (Lavoie, 1986).
} 


\section{References}

Arestis, P. and M. Sawyer (2004) "On fiscal policy and budget deficits", Intervention. Journal of Economics, 1(2), p. 61-74.

Bezemer, D. (2010) "Understanding financial crisis through accounting models", Accounting, Organization and Society, 35(7), p.676-688.

Editors (1978) "A statement of purposes", Journal of Post Keynesian Economics, 1(1), p.3-7.

Fazzari, F.M. (1994-95), "Why doubt the effectiveness of Keynesian fiscal policy?", Journal of Post Keynesian Economics, 17(2), p.231-248.

Galbraith, J. K. (1994-95), "John Maynard Nosferatu", Journal of Post Keynesian Economics, 17(2), p.249-260.

Galbraith, J. K. (2009), "Who are these economists, anyway", Thought and Action, Fall, 85-97. Reproduced" In: D. P. Papadimitriou and G. Zezza (eds), Contributions in Stock-flow Modeling: Essays in Honor Of Wynne Godley, Basingstoke: Palgrave/Macmillan, p. 63-75.

Keynes, J. M. (1936) The General Theory of Employment, Interest and Money, London: Macmillan.

Lavoie, M. (1986) "L'endogénéité de la monnaie chez Keynes", Recherches économiques de Louvain, 52(1), p.67-84.

Lavoie, M. and Seccareccia, M. (1988) "Money, interest and rentiers: the twilight of rentier capitalism in Keynes's General Theory", In: O. Hamouda and J. Smithin (eds), Keynes and Public Policy After Fifty Years: Volume 2: Theories and Methods, Aldershot: Edward Elgar, p. 145-158.

Minsky, H. P. (1986), Stabilizing an Unstable Economy, New Haven (N.J.): Yale University Press. 